Diajukan: 16-01-2019 | Revisi: 05-03-2019 | Diterima: 04-04-2019

\title{
Pengembangan Usaha Mikro, Kecil, dan Menengah Melalui Fasilitasi Usaha Pembuatan Dupa
}

\author{
Novi Primita Sari ${ }^{1}$ \\ Program Studi Ekonomi Pembangunan, Universitas Muhammadiyah Malang ${ }^{1}$
}

\begin{abstract}
Development of Micro, Small and Medium Enterprises (MSMEs) Through Incense Manufacturing Business Facilities (Case Study in Gondang Tegalgondo Village, Karangploso, Malang District). Internal development efforts from household entrepreneurs that produce output in the form of incense to increase potential by using initial capital with their own savings. However, because this business is still a small household business, there are several constraints, including limited human resources, lack of facilities and infrastructure to support production, and packaging of incense products as well as low knowledge about entrepreneurship, resulting in no increase in economic value due to market share the destination is still around Bali and surrounding Malang. The solutions offered to partners are counseling and socialization and discussion with partners. The result of the discussion was that partners began to understand production management efficiently by involving technologies such as incense drying tools that were still being processed, so that even though the rainy season could still produce, partners also got the knowledge that the importance of providing trade name labels related to incense was produced to add value economical on goods produced.
\end{abstract}

Keywords: MSMEs; incense business; technology utilization

\begin{abstract}
Abstrak
Pengembangan Usaha Mikro, Kecil, dan Menengah (UMKM) Melalui Fasilitas Usaha Pembuatan Dupa (Studi Kasus di Desa Gondang Tegalgondo Kecamatan Karangploso, Kab.Malang). Upaya pengembangan secara internal dari pengusaha rumah tangga yang menghasilkan output berupa Dupa untuk meningkatkan potensi dengan cara penggunaan modal awal dengan tabungan sendiri. Namun karena usaha ini masih merupakan usaha rumah tangga kecil sehingga terdapat beberapa kendala diantaranya adalah, keterbatasan sumber daya manusia, kurangnya sarana dan prasarana pendukung produksi, dan pengemasan produk dupa serta masih rendahnya pengetahuan tentang wirausaha, sehingga berakibat tidak adanya peningkatan nilai ekonomi karena pangsa pasar yang dituju masih seputaran Bali dan Malang sekitarnya. Solusi yang ditawarkan kepada mitra adalah penyuluhan serta sosialisasi dan diskusi dengan mitra. Hasil dari diskusi tersebut adalah mitra mulai memahami pengelolaan produksi secara efisien dengan melibatkan teknologi seperti alat pengeringan dupa yang masih baru diproses, sehingga meskipun masih musim hujan masih dapat berproduksi, mitra juga mendapat pengetahuan bahwa pentingnya memberikan label nama dagang terkait dupa yang dihasilkan agar menambah nilai ekonomis pada barang yang dihasilkan.
\end{abstract}

Kata Kunci: UMKM; usaha dupa; pemanfaatan teknologi

\section{Pendahuluan}

Usaha mikro kecil menengah atau yang sering kita sebut sebagai UMKM dewasa ini banyak diminati oleh banyak kalangan, UMKM yang pada mulanya identik dilakukan oleh masyarakat kaum menengah kebawah kini mulai dilakukan oleh semua kalangan. UMKM menjanjikan hasil pendapatan yang cukup baik dan itu berkelanjutan. Perkembangan teknologi dan ilmu pengetahuan yang diimbangi dengan budaya sosial ekonomi turut serta berperan dalam peningkatan jumlah UMKM di Indonesia. Penggunaan teknologi sederhana atau lebih kepada usaha padat karya menjadikan UMKM sebagai sarana penyerapan tenaga kerja, sehingga dapat dikatakan dewasa ini UMKM sangat berkontribusi dalam pengurangan jumlah pengangguran di Indonesia serta mampu memberikan sumbangan pendapatan kepada negara. UMKM menjadi sangat penting karena ini merupakan usaha yang tidak terlalu banyak terpengaruh dengan adanya isu-isu sosial ekonomi seperti melemahnya rupiah akibat menguatnya USD.

Usaha mikro menengah yang banyak berkembang ada di Malang khususnya wilayah Kabupaten Malang. Usaha mikro menengah yang dijalankan adalah aneka olahan makanan, pembuatan kerajinan dan olahan-olahan lainnya. Salah satu industri mikro kecil yang ada di Kabupaten Malang adalah "Pengolahan serbuk kayu menjadi Dupa". Usaha pembuatan dupa ini terletak di Ds. Tegalgondo Gondang Kecamatan Karangploso Kabupaten Malang, yang dikelola sangat sederhana oleh satu rumah tangga dengan 4 pegawai, yaitu suami, istri, dan anak anaknya. Banyaknya sampah-sampah kayu ataupun serbuk kayu yang kurang dimanfaatkan oleh warga Kabupaten Malang, maka muncullah ide pembuatan Dupa.

\footnotetext{
${ }^{1}$ noviprimita@gmail.com
} 
Kendala yang dihadapi oleh industri rumah tangga pengusaha dupa ini mengenai pengembangan usaha serta pengemasan hasilnya. Lokasi pembuatannya yang berada di gang sempit dipinggiran pematang sawah persis dibelakang tempat tinggal mereka, sedangkan dupa yang dihasilkan sudah di ekspor ke sebagian wilayah Indonesia, khususnya ke Bali dan Sumatra serta sebagian kecil wilayah Kabupaten maupun Kota Malang. Permasalahan yang dihadapi oleh pelaku UMKM ini meliputi, kurangnya sarana dan prasarana produksi, lokasi produksi, alat penjemur dupa dari yang masih berupa serbuk basah menjadi bahan kering, pembuatan kayu pegangan dupa yang dikerjakan masih angat manual dengan cara meruncingkan bambu menggunakan tangan tanpa alat apalagi mesin, kurangnya tenaga pembantu produksi, serta cara pengemasan yang tidak memiliki merk dagang.

Beberapa permasalahan tersebut sangat diperlukan perhatian yang lebih dari pemerintah daerah Kab. Malang, khususnya Dinas Koprasi, UMKM, serta Dinas Perdagangan Kabupaten Malang agar UMKM pengahasil dupa ini dapat tumbuh dan berkembang dengan lebih baik, karena dampak yang diharapkan dari pengembangan usaha ini akan berdampak pada peningkatan perekonomian masyarakat khususnya masyarakat sekitar lokasi. Penelitian ini bertujuan untuk mengetahui, mendeskripsikan dan meng-analisis pengembangan Usaha Mikro, Kecil, dan Menengah (UMKM) melalui fasilitasi pihak eksternal dan potensi internal pada kelompok usaha "Pembuatan Dupa dari Serbuk Kayu" di wilayah Ds Gondang Tegalgondo, Kecamatan Karangploso Kabupaten Malang. Yang kedua penelitian ini bertujuan untuk mengetahui, mendeskripsikan dan menganalisis kendala dalam pengembangan Usaha Mikro, Kecil, dan Menengah (UMKM) pada usaha "Pembuatan Dupa" di Ds Gondang Tegalgondo, Kecamatan Karangploso Kabupaten Malang. Media elektronik moneyinsight membahas tentang bisnis dupa kaori yang juga memiliki nama dagang terkenal diantara pembisnis dupa, memiliki permasalahan hampir sama yaitu bahan baku serbuk kayu yang digunakan apabila tanpa tambahan teknologi mesin kualitas dan kuantitasnya akan berkurang serta para pesaing usaha yang membeli dupa kiloan untuk kemudian dikemas kembali, salah satunya juga dibuat oleh dupa rumah tangga di Tegal Gondo ini.

Rendahnya pengetahuan mitra dalam pemanfaatan teknologi pengeringan sehingga masih menggunakan cahaya matahari sebagai sumber pengeringan utama dalam produksi. Pengetahuan tentang pembuatan batang dupa yang masih manual menggunakan peruncingan dan pemotongan dengan pisau, sehingga waktu kurang efisien dalam produksi. Pengemasan yang tidak mencantumkan nama dagang sehingga kurang memiliki nilai jual ekonomi yang baik. Kurangnya tenaga sumber daya manusia karena masih dikerjakkan 1 keluarga yang melibatkan suami, istri dan anak, baik dari segi pembelian bahan baku, proses produksi hingga pengemasan dan kemudian pendistribusian.

Tujuan dari kegiatan pendampingan ini adalah memberikan tambahan pengetahuan bagi mitra mengenai pemanfaatan teknologi yang ada dalam proses produksi agar kegiatan produksi dupa berjalan dengan cepat dan efisien serta memberikan motivasi kepada mitra sesuai dengan usaha yang sedang dilakukan serta motivasi pengembangan usaha dengan mencantumkan merk dagang sendiri dari produk dupa yang dihasilkan.

Manfat dari kegiatan ini adalah meningkatkan kemampuan dan pengetahuan bahwa pentingnya memanfaatkan teknologi dalam proses produksi agar kegiatan produksi menjadi lebih efisien dan meskipun musim penghujan mitra tidak terkendala ketika memasuki proses pengeringan dupa, memberikan motivasi kepada mitra untuk mencantumkan merk dagang agar masyarakat luas tahu bahwa ada produksi dupa disekitar wilayah tersebut. Menambah pengetahuan mitra tentang pentingnya perhitungan keuangan, agar mitra mengetahui jumlah dana yang digunakan untuk produksi dan pendapatan yang dihasilkan, agar mitra semakin paham berapa profit yang dihasilkan dari usaha yang telah dijalani selama ini.

\section{Materi dan Metode Pelaksanaan}

Materi pelaksanaan program ini terdiri dari :

1. Strategi Pengelolaan Sumber Daya Manusia

Menurut Yahya \& Goh, dalam Latifa 2018, area manajemen sumber daya manusia itu didasarkan pada pelatihan, proses pengambilan keputusan dan penilaian kinerja. Kegiatan pengabdian ini dilakukan dengan cara memberikan wawasan serta pemanfaatan teknologi dalam proses produksi yang disesuaikan dengan kemampuan mitra itu sendiri.

2. Analisis Kelayakan Usaha

Analisis terkait kelayakan usaha dilakukan guna memberi gambaran terkait kebutuhan mitra dalam proses pengembangan usaha serta menghitung asumsi hasil penjualan serta pengeluaran agar dapat diketahui secara cermat apakah usaha produksi dupa itu layak atau kurang layak. Metode pendekatan yang dilakukan dalam proses pengabdian ini adalah:

a. Berdiskusi secara langsung kepada mitra terkait kendala yang mungkin ditemui saat proses produksi, dari perolehan bahan baku sampai menjadi output. 
b. Memberikan pengetahuan terkait wirausaha kepada pihak yang menjadi mitra

c. Memberikan saran dan solusi untuk peningkatan nilai produk secara ekonomis melalui proses

d. pengemasan yang baik dan mencantumkan nama dagang produk dupa yang dihasilkan.

e. Melakukan pendampingan secara berkala dalam proses produksi dupa, yang meliputi menganalisis usaha, kualitas produk, pengemasan, diskusi dan sambil mempraktekkan secara langsung.

\section{Hasil dan Pembahasan}

Produksi pembuatan dupa yang dimulai dari pembuatan batang dupa sampai pembuatan adonan serbuk kayu menjadi dupa yang kemudian dikeringkan ditempat yang sama, yaitu pematang sawah. Penggunaan oven listrik maupun oven sederhana disarankan agar kegiatan produksi menjadi lebih efisien, karena mereka tidak akan terkendala dalam proses terkait pengeringan dupa meskipun sedang musim penghujan. Perubahan teknologi (technological change) adalah perubahan dalam fungsi produksi dalam suatu kegiatan tertentu yang mana dapat menambah hasil dengan input tertentu. Perubahan teknologi ini menyebabkan tambahan produksi dengan sumber-sumber yang sama ataupun jumlah output yang sama tetapi dengan input yang lebih sedikit atau mungkin pula berupa barang-barang yang baru yang punya kegunaan yang lebih banyak. Jadi bukan dalam jumlah barang yang lebih banyak untuk barang-barang yang sama. Selain itu karena penggunaan teknologi pemasaran yang masih minim mengakibatkan pemasaran produk Dupa di Desa Gondang masih sebatas hanya pelanggan lama tanpa ada perkembangan dan penambahan pelanggan baru.

Proses pemasaran dalam UKM memiliki peranan yang penting karena semakin baik tingkat pemasaran maka perkembangan usaha juga akan mengalami peningkatan. Penelitian terdahulu milik (Jauhari, 2010), yang menjelaskan bahwa pemanfaatan E-commerce dalam kegiatan penjualan dan pemasaran memiliki banyak keuntungan yakni, cakupannya yang luas, tidak mengenal ruang dan waktu serta dapat dilakukan kapan saja dan dimana saja. Sehingga penggunaan E-commerce selayaknya dicoba dan digharapkan mampu membantu mengembangkan UKM yang ada di Indonesia. Pengetahuan masyarakat mengenai wirausaha masih tergolong sangat rendah, apabila masyarakat memiliki pengetahuan tersebut maka akan sangat bermanfaat sebelum mendirikan usaha. Usaha pembuatan dupa tidak banyak orang yang mengetahui manfaat dari limbah kayu, biasanya limbah kayu atau serbuk kayu hanya digunakan sebatas untuk bahan bakar untuk proses memasak tradisional.

Materi yang diberikan terkait pengetahuan kewirausahaan adalah profit atau keuntungan ketika memiliki sebuah usaha, meliputi efisiensi waktu, tidak terikat kerja dengan siapapun dan keuntungan di dalam jangka panjang. Kegiatan pendampingan berbentuk diskusi ini hanya diikuti oleh mitra yang bersangkutan, karena usaha ini masih skala rumah tangga namun sudah dapat mengekspor hasil usahanya meliputi wilayah Bali dan Sumatra. Industri UKM juga masih sangat minim pengetahuan mengenai manajemen keuangan hal ini di sebabkan kurangnya kemampuan manajerial dan financial, pernyataan ini sesuai dengan penelitian terdahulu yang dilakukan, Hapsari (2014).

\section{Kesimpulan dan Saran}

Kegiatan pengabdian masyarakat produksi dupa yang dilaksanakan di Dusun Gondang, Desa Tegalgondo, Kecamatan Karangploso Kabupaten Malang ini dapat disimpulkan bahwa sulitnya perolehan bahan baku serbuk kayu dan pembuatan batang dupa yang masih dilakukan secara manual menghambat proses produksi. Kemudian teknik pengeringan yang masih sangat tradisional yang masih memanfaatkan sinar matahari juga turut memberikan dampak kurangnya hasil produksi ketika memasuki musim penghujan, sehingga terkadang mitra kurang bisa memenuhi permintaan konsumen. Analisis yang dilakukan melalui situasi rendahnya pengetahuan mitra terkait pengelolaan keuangan juga turut andil dalam ketidakefisienan kegiatan produksi selama ini, karena tidak adanya sistem pengupahan mengingat yang menjadi SDM adalah semua keluarga mitra yang meliputi, suami, istri dan anak-anak mereka sehingga kurang begitu jelas pendapatan serta pengeluaran rutin yang dilakukan selama ini.

Hasil dari kegiatan pendampingan mitra menunjukkan bahwa mitra sudah mengetahui dan memahami tentang pengelolaan sumber daya produksi yang mereka miliki dengan cukup baik. Mitra dalam kegiatan pengabidan juga telah memperoleh peningkatan wawasan tentang wirausaha, di sisi lain mitra juga telah mampu melakukan analisis kelayakan usaha dari segi pengelolaan keuangan yang meliputi pengeluaran tetap dan pendapatan sehingga hasil profit atau keuntungan dapat terlihat lebih jelas. 


\section{Ucapan Terimakasih}

Terselesaikannya kegiatan pengabdian masyarakat yang berbentuk pendampingan terhadap mitra ini, maka saya ucapkan terimkasih yang sebesar-besarnya kepada mitra bapak Isrofi dan ibu selaku mitra yang melakukan produksi pembuatan dupa. Terimakasih juga kepada suami saya yang setia mendampingi saya selama proses terjun kelapangan di Dusun Gondang-Desa Tegalgondo, Kecamatan Karangploso Kabupaten Malang dan terimakasih untuk seluruh warga RT 05 yang telah membantu dan mendukung terlaksananya kegiatan ini.

\section{Referensi}

Hapsari, Ira Maya (2014). Identifikasi berbagai permasalahan yang dihadapi oleh ukm dan peninjauan kembali regulasi ukm sebagai langkah awal revitalisasi UKM. 5(2), 43-47.

Jauhari, jaidan. 2010. Upaya pengembangan usaha kecil dan menengah (UMKM) dengan memanfaatkan e-commerce. Jurnal Sistem Informasi. Volume 2 Nomor 1.

Latifa 2018, IBM Dusun sukosari desa pandansari poncokusumo kabupaten malang. jurnal studi kasus inovasi ekonomi. Vol. 02 No. 01 Maret 2018 Hal. 1-6.

Yahya \&Goh,2002, Managing human resources toward achieving knowledge management. Journal of Knowledge Management. 6(5). 457-468.

https://moneyinsight.id/winie-kaori-harum-bisnis-semerbak-dupa/

http://infoseputarekonomi.blogspot.com/2016/10/pentingnya-penggunaan-teknologi-dalam.html 